\title{
Zaufanie jako składowa i uwarunkowanie kapitału społecznego: ukraińskie doświadczenie kształtowania
}

\section{Confidence as a Component and Prerequisite of Social Capital: Ukrainian Experience of Forming}

\begin{abstract}
Confidence as a basic premise of social capital formation is analyzed in this article. Risks of losing confidence for society sustainable development are proved. The place of confidence in the structure of social capital is determined. The processes of confidence change by Ukrainians during the revolutionary events of 2013-2014 is researched.
\end{abstract}

Keywords: confidence, social capital, social networks, social solidarity.

Słowa kluczowe: zaufanie, kapitał społeczny, sieci społeczne, solidarność społeczna

Mimo różnic w interpretowaniu przez badaczy istoty kapitału społecznego, większość z nich uznaje, że kształtuje się on przez istnienie ogólnych norm i wartości, wzajemnego zaufania i sieci powiązań społecznych. Kapitał społeczny, uosobiony w postaci norm, tradycji, solidarności oraz współpracy, stanowi ważną przesłankę rozwoju społeczeństwa.

Obecnie teorie zaufania krzyżują się z koncepcjami kapitału społecznego, w wyniku czego powstaje samodzielny kierunek badań - badanie zaufania jako składowej kapitału społecznego. We współczesnym dyskursie politologicznym problem zaufania staje się jednym z najbardziej aktualnych, ponieważ gwałtowne i niespodziewane zmiany społeczno-polityczne podważają zaufanie jednostki zarówno do instytucji państwowych, jak i do siebie, co uniemożliwia budowanie społecznego dialogu. Wywiera to destrukcyjny wpływ na funkcjonowanie poszczególnych dziedzin życia społecznego. Zaufanie stanowi część integralną komunikacji, stosunków społecznych na wszystkich poziomach organizacji, a deficyt zaufania powoduje zaburzenia zasad stosunków społecznych. 
Aktualność badania problematyki zaufania wynika z konieczności poszukiwania mechanizmów zapewniania stabilności społecznej, trwałości, przewidywalności relacji społecznych, minimalizacji ryzyka. Jakie warunki zapewniają konstruktywny dialog społeczny? Jak kształtuje się kapitał społeczny i jakie efekty przynosi? Jak zaufanie wpływa na jakość życia, na rosnącą obcość w relacjach między społeczeństwem a państwem, człowiekiem a władzą? Są to zagadnienia otwarte dla przestrzeni badawczej, czekające na odpowiedź. Wciąż nie jest zbadany także problem: w jaki sposób kapitał społeczny, jako znaczący aktyw niematerialny związany jest z rozwojem ludzkości, z możliwościami odkrycia potencjału jednostki, grupy społecznej, instytucji i wreszcie społeczeństwa ukraińskiego?

Największy wkład w badania fenomenu zaufania wnieśli Benjamin Barber, Anthony Giddens, John Coleman, Niklas Luhmann, Robert D. Putnam, Francis Fukuyama, Piotr Sztompka. Kierunek badania zaufania jako składowej kapitału społecznego został przedstawiony w pracach Pierre'a Bourdieu, Niklasa Luhmanna, Roberta D. Putnama, Francisa Fukuyamy, założycieli naukowej tradycji analizy kapitału społecznego za pomocą kategorii „zaufania”. Mimo znacznej ilości publikacji, stopień naukowego opracowania tematu charakteryzuje się fragmentarycznością teoretyczną. Większość naukowców łączy kapitał społeczny z zaufaniem, jednak brak wyraźnie określonego miejsca zaufania w strukturze kapitału społecznego.

Celem badania jest analiza zaufania jako składowej kapitału społecznego, funkcjonowania zaufania i jego wpływu na kształtowanie kapitału społecznego. Obecnie brak nie tylko wyraźnego określenia miejsca zaufania w strukturze kapitału społecznego, lecz również ogólnie przyjętego modelu struktury kapitału społecznego.

$\mathrm{Na}$ kapitał społeczny składają się trzy elementy: stosunki społeczne, sposoby komunikowania się; wzajemne relacje. Mechanizmy kształtowania kapitału społecznego można podzielić na: mechanizmy kształtowania i utrwalania norm społecznych, w tym norm współdziałania społecznego oraz mechanizmy kształtowania zaufania społecznego 1 .

Zdaniem P. Sztompki, fenomen zaufania należy rozumieć jako wyrażone wobec partnera oczekiwanie, że jego działania będą dla nas korzystne ${ }^{2}$. Według autora zaufanie - to pozytywna, moralno-etyczna, pragmatyczna lub emocjonalna ocena.

1 Механизмы формирования сочиального капитала, http://www.svn-s.ru/ppage07_57.php, odczyt z 1.04.2014.

2 П. Штомпка, Аоверие: сочиологическая теория, Социологическое обозрение, 2002, nr 3, s. 30-41. 
W systemie stosunków społecznych fenomen zaufania jest podstawowym sposobem kształtowania i gromadzenia kapitału społecznego, integratorem, tworzącym całość. Miejsce zaufania w systemie kapitału społecznego decyduje o tym, że stanowi on zasób niematerialny; stanowi efekt relacji między podmiotami, opartymi o zaufanie, solidarność, tolerancję; jest regulowany normami, wartościami oraz determinowany ryzykiem, kontrolą i nieufnością. Stanowi on potencjał do działania społecznego, co jest wynikiem zaufania pomiędzy i wewnątrz różnych grup i wspólnot ludzkich. Wzajemne zaufanie jest jednym z podstawowych mierników kapitału społecznego ${ }^{3}$. Zdolność do tworzenia grup powstaje wtedy, gdy jej członkowie mają nie tylko wspólne interesy, lecz również oczekują uczciwego i niezawodnego zachowania ze strony innych. Zaufanie, oparte na wierze i nadziei, pomaga we współdziałaniu, łączeniu wysiłków, w dostępie do obiektywnych informacji. Zaufanie jest „smarem” (Francis Fukuyama) ${ }^{4}$, który ułatwia społeczną kooperację, utrwala więzi społeczne oraz obniża ryzyko konfliktów. John Coleman twierdził, iż kapitał społeczny - jest to potencjał wzajemnego zaufania i pomocy, kształtowany w stosunkach międzyludzkich przez zobowiązania, oczekiwania i normy społeczne $e^{5}$

Zaufanie jako czynnik, instrument i środek gromadzenia kapitału społecznego odzwierciedla aktualne, przeszłe, jednostkowe i społeczne doświadczenie grupy. Niesie w sobie także pamięć społeczną. Występuje jako konstrukcja społeczna, oparta na pewności i trwałości współdziałania społecznego. Niedocenianie tego czynnika doprowadza do nieracjonalnego marnowania czasu, zbędnego wydatkowania środków, a wreszcie obniżenia potencjału adaptacyjnego ludności ${ }^{6}$. Zaufanie stanowi bowiem podstawę zrozumienia społecznego. Kształtuje orientację, zdolność, pragnienie i gotowość do współpracy, dialogu i partnerstwa.

Relacje zaufania - nieufności między podmiotami społecznymi w dowolnej dziedzinie mają konstruktywny lub, odwrotnie, destruktywny charakter. W pierwszym przypadku powstaje zrozumienie, dialog między podmiotami społecznymi; w razie nieufności więzi zostają utracone, a interesy społeczne partnerów ulegają ograniczeniu.

3 Н. Аевчук, Асочіальні явища як наслідок дефічиту соціального капіталу в Україні, Український соціум, 2011, nr 1, s. 138.

4 Ф. Фукуяма, Аоверие: социальные добродетели и путь к процветанию, Москва 2006, s. 730 .

5 Аж. Коумман, Капитал социальныци и человеческий, Общественные науки и современность, 2001, nr 3, s. 124.

6 О. Панькова, Аоверие как основа формирования сочіального капитала в контексте развития человеческого потенциала Украиньь, Актуальні проблеми соціології, психології, педагогіки, 2012, nr 16, s. 104. 
Jednym z elementów, przyczyniających się do kształtowania i wzrostu kapitału społecznego jest zaufanie obywateli do państwa. W państwach byłego Związku Radzieckiego obserwowalna jest tzw. postsowiecka tendencja, czyli wysoki poziom nieufności obywateli w stosunku do organów władzy państwowej. Wynika to z jej obojętności wobec problemów obywateli, skorumpowania, pragnienia utrzymania się na wysokich stanowiskach, nadużywanie stanowisk służbowych, amoralności, nieuczciwości, itp.

Do obliczenia narodowego zakresu „kapitału społecznego” stosowane są dwa wskaźniki: wskaźnik zaufania i członkostwo w stowarzyszeniach. Przybliżony poziom kapitału społecznego mierzony jest za pomocą metod ankietowych. Jednak najbardziej dokładne informacje, dotyczące jego stanu można uzyskać za pomocą regularnego monitorowania procesów, związanych z rozwojem i utrwaleniem zaufania społecznego w społeczeństwie. Ukraińskie ośrodki socjologiczne odnotowują stały proces obniżania zaufania do wszystkich instytucji państwowych: głowy państwa, parlamentu, rządu, organów sądowych i wymiaru sprawiedliwości. Stosunkowo wysokie jest zaufanie do cerkwi, niepaństwowych środków masowego przekazu, organizacji społecznych. Zaufanie do wojska waha się, jednak przeważa zaufanie, które w sposób oczywisty wzrasta pod wpływem krymskich wydarzeń wojennych 2014 r. ${ }^{7}$ Silnym bodźcem zmieniającym strukturę zaufania ludności, stały się wydarzenia na Ukrainie, które zaczęły się w listopadzie 2013 r. przez wstrzymanie kursu integracji europejskiej.

Uwidoczniła się tendencja trwałej nieufności nie tylko do władz, lecz również do partii politycznych. Świadczą o tym hasła antypartyjne, wysunięte przez Euromajdan („Politycy precz!”, „Partie precz!”) oraz ograniczenie symboliki partyjnej podczas wieców. Zaufanie do partii zostało zrujnowane głównie działaniami działaczy partyjnych. Zaufanie do rządu zmniejszyło się przez korupcję władzy oraz masowe zubożenie. Dla wielu ludzi pozostaje tylko wiara w Boga, a przez nią - zaufanie do cerkwi. Społeczeństwo Ukrainy wyraża najwyższy poziom zaufania do rodziny, a od stycznia/lutego 2014 r. odnotowuje się ogromny wzrost zaufania do różnego rodzaju organizacji samoobrony, patroli, zorganizowanych przez obywateli w celu zapewnienia porządku publicznego.

Niezbędnym warunkiem wzrostu zaufania jest regularne informowanie przez władze ludności o wynikach swojej działalności. Dla przywrócenia zaufania w społeczeństwie państwo przede wszystkim powinno prowadzić politykę: „nie kłam”,

Українці найбільме довіряютьь церкві, українським ЗМI та армї - опитування, httр:// ua.korrespondent.net/ukraine/politics/3365342-ukraintsi-naibilshe-doviriauit-tserkvi-ukrainskymzmi-ta-armii-opytuvannia, odczyt z 1.04.2014. 
„nie zawiedź”, „spełnij obietnice”. Opóźnienie wpłat wynagrodzenia pracownikom budżetowym, ograniczenie praw człowieka, poczucie bezradności obywateli wobec politycznych gier pogłębiają stopień nieufności do władz. W tej sytuacji władza powinna podjąć kroki w celu przywrócenia wzajemnego zaufania, postępując uczciwie i otwarcie wobec swoich obywateli.

Dla przywrócenia zaufania ludzi do organów władzy państwowej niezbędne są także: regularne informowanie obywateli o transparentności i otwartości władz; rozwój informacyjny społeczeństwa; niezależne media. Do rozwoju zaufania w układzie „władza - obywatel” przyczynia się także e-rządzenie, które usprawnia działania władz oraz ułatwia dostęp obywateli do informacji i usług oraz zapewnienia satysfakcję z procesu rządzenia. Na przykład, portal rządowy w Singapurze nie tylko udziela informacji o organach państwowych, lecz również zezwala na dokonanie czynności, które wcześniej można było zrealizować wyłącznie w urzędzie. E-rządzenie stało się synonimem współczesnego nowoczesnego państwa, którego podstawą są jakość, zaufanie i szybkość działania ${ }^{8}$. Stosowane we właściwy sposób mechanizmy e-rządzenia są w stanie scementować relacje między władzą a obywatelami, pomagając w budowie zaufania społecznego. Dlatego na całym świecie aktywnie wspiera się wprowadzanie metod e-rządzenia we wszystkie sfery relacji państwa z obywatelami. Jednym z aspektów e-rządzenia jest bowiem zaangażowanie obywateli w podejmowanie ważnych, strategicznych decyzji w państwie?.

Istotnym instrumentem współdziałania państwa i społeczeństwa przy pomocy współczesnych technologii informatyczno-komunikacyjnych są e-konsultacje, np.: strona WWW, na której przedstawione są pytania do obywateli; możliwość komentowania zamieszczonych on-line artykułów lub dokumentów; konferencje on-line, pozwalające na wirtualne zebranie uczestników fizycznie oddalonych od siebie; korzystanie z narzędzi internetowych (e-poczty); czat, który dzięki rozwiniętemu oprogramowaniu pozwala na kontakt w czasie rzeczywistym, nawet jeżeli intensywność dialogu jest ograniczona; ankietowanie on-line itp.

Rozwój kultury zaufania na Ukrainie stanowi podstawowy warunek do kształtowania jedności społecznej, osiągnięcia ogólnonarodowej zgody i adaptacji ludności do zmiennych warunków, odkrycia potencjału ludzkiego tak społeczeństwa, jak i jednostki. Deficyt zaufania blokuje potencjał, wyczerpuje zasoby i świadczy o chorobliwym stanie organizmu, co negatywnie odbija się na rozwoju społecznym, gospodarczym i ludzkim kraju.

8 А. Митко, Електронна демократія в дї, Науковий вісник Волинського національного університету імені $\Lambda$ есі Українки, 2011, nr 20 (217), s. 20-23.

9 Ibidem. 
Kształtowanie i nagromadzenie kapitału społecznego na mikro- i makropoziomach, którego podstawowym zasobem jest zaufanie, staje się niezbędnym warunkiem zdolności do życia społeczeństwa, jego instytucji i struktur społecznych, powołanych do tego, by funkcjonować dla dobra człowieka. Zmiana kultury współdziałania jakościowo wpływa na system relacji między ludźmi, grupami społecznymi, otwierając nowe perspektywy. Problem dotyczy szczególnie współczesnej Ukrainy.

Fenomeny samoorganizacji i kształtowania wzajemnego zaufania można zilustrować na przykładzie wydarzeń we Lwowie w 2014 r. Aktywność społeczna w miastach przejawiała się w przyjmowaniu i osiedleniu krymskich Tatarów uchodźców (z dnia 5 marca 2014 r.), przyjęciu do miejscowych szpitali poszkodowanych na Majdanie. Obywatelski Sektor we Lwowie zaktywizował licznych wolontariuszy, którzy chcieli pomagać potrzebującym rodakom. Podczas działań bojowych na Majdanie Lwowianie zajmowali się produkowaniem kamizelek kuloodpornych, zbieraniem środków i wysyłaniem ich do Kijowa. Siłami społeczeństwa realizowany jest ruch „Lustracja Obywatelska” oraz projekt telewizyjny „Lustracja”. Grupa „Stop łapówka” jest jedną z najbardziej aktywnych wspólnot, stworzonych przez przedstawicieli środowiska biznesowego obwodu lwowskiego, nienależących do partii politycznych. Aktywiści wspólnoty „Bojkot gospodarczy regionałów. Lwów” organizują bojkotowanie rosyjskich towarów w związku z inwazją wojsk Rosji na Krymie.

Przykładem aktywności społecznej jest Lwowski Narodowy Uniwersytet im. Iwana Franki. Wspólnoty „Uniwersytecki Majdan” oraz „Kontrola jakości oświaty i nauki w Lwowskim Narodowym Uniwersytecie" poruszają zagadnienia reform i zmian edukacji uniwersyteckiej, a także poszukiwania sposobów, przy pomocy których mogliby naprawiać Uniwersytet od wewnątrz: samorząd uniwersytecki, autonomia uniwersytetów, modernizacja, dialog pomiędzy administracją, studentami i wykładowcami, jakość oświaty.

Po „Nocy gniewu” (18-19.02.2014) Lwowianie własnoręcznie zorganizowali akcję „Posprzątaj swoje miasto”, zapewniali porządek publiczny, koordynując swoje działania z funkcjonariuszami milicji: patrole pieszych, rowerowe i samochodowe (ponad dwa tysiące osób). Skuteczne okazały się inicjatywy społeczne: "Samochodowa ochrona miasta”, „Autosetka” - Hufiec Samoobrony, „Galicki Legion”, „Nocna warta”, „Kontrola drogowa”. Patrolowanie samochodowe odbywało się przeważnie w nocy; zarejestrowane w centrach koordynacyjnych auta, miały specjalne oznakowania, a działania uzgadniały przez radiostację. Lwowianie samoorganizowali się wobec zagrożenia szabrownictwa i masowych, sprzecznych z prawem czynów, w celu zapewnienia porządku publicznego. 
Analogiczne przykłady aktywności zaobserwować można było także w innych częściach Ukrainy. Znamienne są doświadczenia okupowanej Autonomicznej Republiki Krymu. Nie ma tu jednej bazy, dokąd można przynosić jedzenie, leki, ubrania, pieniądze; brak jest centrum koordynacyjnego (od dnia 27.02.2014 r. działa inicjatywa „Krym SOS”), skąd mogłyby brzmieć wyraźne rozkazy dla organizacji społecznych, wolontariuszy, itp. Jednak, mimo niebezpieczeństw, organizowane są dziesiątki inicjatyw pomocy: dyżury pokojowe mieszkańców wokół jednostek wojskowych, pomoc rodzinom wojskowych, poszukiwanie mieszkań dla rodzin, które postanowiły wyjechać z Krymu, organizacja pokojowych akcji protestacyjnych, wsparcie dziennikarzy krajowych i zagranicznych, pomoc wojskowym w jednostkach zablokowanych, tworzenie „żywych tarcz” koło magazynów broni w jednostkach wojskowych, antywojenne manifestacje. Wszystko koordynowane jest w trybie telefonicznym lub przez portale społecznościowe. Żołnierze armii ukraińskiej otrzymują tysiące listów ze słowami poparcia; Tatarzy krymscy, Ukraińcy i Rosjanie w wielu miejscowościach Krymu tworzą ludowe drużyny w celu informowania ludzi o rzeczywistej sytuacji, zwłaszcza wobec powszechnego wyłączania kanałów telewizyjnych i porywania dziennikarzy.

Jeśli opierać się na tezie, że kapitał społeczny kształtuje się z prywatnego kapitału ludzkiego, to rewolucyjne i wojenne wydarzenia lat 2013-2014 w sposób istotny zmieniły wielu obywateli Ukrainy: dojrzała świadomość potrzeby zmian, ale własnym wysiłkiem. Wśród głównych haseł zmian znajdują się: samoorganizacja, rozszerzenie zakresu odpowiedzialności. Utrwala się świadomość osobistej odpowiedzialności za własne życie, sukces, dobrobyt oraz potrzeba podejmowania odpowiedzialności za siebie i swoich bliskich. „Zabijanie wirusa” obojętności wewnątrz siebie, aktywizacja więzi międzyludzkich - jest to zdecydowany skok do jakościowo-ilościowego wzrostu kapitału społecznego. W okolicznościach nadzwyczajnych osiągnięte na dany moment wzajemne zaufanie obywateli stanowi krok do zjednoczenia, wspólnej sprawy, a więc społecznego kapitału Ukraińców. W tym aspekcie kapitał społeczny stanowi potencjał wzajemnego zaufania i pomocy, która kształtuje się w stosunkach międzyludzkich. W aktywnym współdziałaniu indywidualny kapitał społeczny człowieka staje się wartością dla wspólnoty. 